security of Australia and of stability in the Pacific. $\mathrm{He}$ struck to the root of the matter, however, when he reminded his hearers that Australia in her administrative policy in New Guinea has been actuated by the British conception that colonial possessions are trusts to be administered in the best interests of the native populations. In support of this contention, Sir George pointed out that in present conditions the natives of the territory formerly German New Guinea are better protected, and that the development of roads, shipping, air transport and medical and educational services have contributed to their well-being and contentment. It is perhaps worth while to add, for the benefit of those who have not followed closely the extension of the administrative services of Papua to German New Guinea since the latter became a mandated territory, that this successful result is not fortuitous. It arises out of the efforts which have been made on behalf of the Australian Government to add to scientific knowledge of the country and people, and the administration's far-sighted adaptation of that knowledge to the needs of the situation.

\section{Flying Boats for North Atlantic Air-Routes}

Is addition to the specially fitted Short flying boats, and the Mayo composite aircraft mentioned in NATURE of March 7, p. 390, an order has now been placed for two four-engined De Havilland monoplanes for experimental Atlantic flights. It is understood that a regular North Atlantic air mail service is first visualised, which will be thoroughly tried out before passenger services are attempted. The new De Havilland machines are based, in design, on the 'Comet' type, that won the recent England to Melbourne air race, and bear a strong resemblance to them in general appearance. They are monoplanes, with the four 'Gipsy' engines partially buried in the wings, and are fitted with retractable undercarriages. The bodies of the machines are constructed so as to float in the event of a forced landing on the water, and additional buoyancy is given by a watertight construction of the wings. Messrs. De Havilland's method of fabrication, as used on the 'Comet', lends itself very well to this requirement. It is estimated that the cruising speed of the machines will be more than two hundred miles an hour, with an air endurance of three thousand miles. This same type should also be suitable for long-range high-speed naval reconnaissance. It is anticipated that these machines will be ready for delivery by November or December next.

\section{New Fruit Products}

Fon the past few years the Fruit Products Depart. ment of the University of Bristol Research Station at Long Ashton has been engaged in the experimental production of various wines, syrups, squashes, liqueurs, etc., prepared from the common varieties of fruits grown commercially in Great Britain. The work has now reached a stage where many of the products are capable of commercial manufacture, and on March 11 a demonstration was held at which an opportunity was provided for representatives of food and beverage manufacturers and others in. terested in the industry to sample the various new preparations. Several fruit syrups were available which retained the natural flavour of the fruit after being stored for a number of years. These were particularly attractive in conjunction with cream ice in the American fashion, strawberry and loganberry syrups being outstanding examples. The juices of these two fruits were also successfully made into pleasing wines, whilst a spirit distilled from straw. berry juice and flavoured with loganberry syrup made an attractive liqueur. Fruit squashes were also represented, that from black currant being of particularly pleasing quality. A number of non-alcoholic apple juices were displayed, and methods of storing these beverages without fermentation were demonstrated. In view of the probable rapid development of milk bars, much interest was shown in the 'milk shakes' prepared from a wide variety of pure fruit syrups, and data were presented to show that curdling of the milk does not normally occur at ordinary temperatures. The ultimate object of this work is to provide new outlets for fruit, in addition to those already existing through the fresh-fruit markets and the canning and jam industries. It is anticipated that this will lead to a considerable increase in fruit growing in Great Britain, whilst at the same time the grower will be assured of disposing of the bulk of his crop, and the serious wastage hitherto associated with glut crops will be considerably reduced.

\section{Bibliography of Natural History}

ON March 14, a meeting was held at the Royal Entomological Society of London to consider the foundation of a society for the study of the biblio. graphy of natural history. Dr. C. Davies Sherborn, in opening the meeting, gave a brief statement as to the reason for the summoning of the meeting, and invited those present to express their views as to the desirability of establishing a society. In the discussion which ensued, warm approval was expressed with the proposal to found a society, especially in view of the suggestion that such society should undertake the publication of a journal to which interested persons could turn for information on matters concerning the bibliography of natural history. At the conclusion of the discussion, Mr. W. L. Sclater moved "that a Society for the study of the bibliography of natural history be founded, those persons here present, together with those who had signified their agreement with the aims of the Society and were unable to be present, being constituted Original Members'. This proposal, seconded by Dr. Karl Jordan, was carried unanimously. It was then decided to appoint the following committee to deal with the preliminary details, and the committee was instructed to call a general meeting in three months' time: Dr. C. Davies Sherborn, Prof. W. A. F. Balfour-Browne, Francis Hemming, J. Ramsbottom, Dr. T. A. Sprague, A. Cockburn Townsend, Francis J. Griffin. All inquiries should be addressed to Mr. F. J. Griffin at 41 Queen's Gate, South Kensington, S.W.7. 